\title{
De IQ-score in twijfel getrokken: Evolutie naar een multidimensioneel cognitief vaardigheidsprofiel
}

Een illustratie uit de forensische psychiatrie

\author{
K. Uzieblo, P. Habets, I. Jeandarme
}

\begin{abstract}
Samenvatting
Een foutieve of ontoereikende inschatting van het intellectueel functioneren kan verstrekkende gevolgen hebben binnen de forensische context. Niet zelden worden beschermings- en strafmaatregelen afgestemd op de intellectuele vaardigheden van de pleger. Een kwalitatieve bepaling van dit functioneren is dan ook van groot belang. Dit blijkt echter geen vanzelfsprekend gegeven te zijn. Een recente studie naar de stabiliteit van herhaalde IQ-metingen bij Vlaamse forensische patiënten $(n=176)$ (Habets et al., J Appl Res Intellect Disabil., 2014) geeft aan dat verschillende intelligentietesten en herhaalde metingen van eenzelfde intelligentietest niet steeds gelijkaardige resultaten opleveren. Scores verkregen op basis van intelligentietesten blijken dus niet zonder meer inwisselbaar te zijn. De huidige studie beoogt een kritische blik te werpen op de waarde van deze intelligentiemetingen en op de recente ontwikkelingen binnen dit veld. Meer specifiek worden de mogelijke oorzaken van de instabiliteit van IQscores besproken. Aansluitend worden de belangrijkste ontwikkelingen aangaande de diagnostiek van het intellectueel functioneren uiteengezet. Een gewijzigd denkkader treedt de laatste jaren immers meer en meer op de voorgrond, waarbinnen de klemtoon stelselmatig van een IQ-score naar het in kaart brengen van een breed cognitief vaardigheidsprofiel en het adaptief functioneren verschuift.
\end{abstract}

Trefwoorden IQ · cognitieve vaardigheden $\cdot \mathrm{CHC} \cdot \mathrm{DSM} 5 \cdot$ WAIS $\cdot$ plegers

K. Uzieblo ( $\square)$

Thomas More,

Antwerpen, Belgie

e-mail:kasia.uzieblo@thomasmore.be

K. Uzieblo

Universiteit Gent,

Gent, België

P. Habets $\cdot$. Jeandarme

Kenniscentrum Forensisch Psychiatrische Zorg (KeFor),

OPZC Rekem,

Rekem, België

\section{Inleiding}

Ik werk als psycholoog in de gevangenis met geïnterneerden met een verstandelijke handicap. In expertiseverslagen wordt er vaak gebruikgemaakt van de Progressieve Matrices van Raven. Later in het traject wordt er soms nog een WAIS-III afgenomen en de resultaten op deze testen kunnen zeer uiteenlopend zijn. Zo hebben we bij een bepaalde patiënt bijvoorbeeld een IQ-score van 54 met 
de Progressieve Matrices verkregen, terwijl de WAIS-III dan weer een IQ-score van 88 aangeeft. Dit is nu één voorbeeld, maar dergelijke over- of onderschattingen komen we vaak tegen. Ik las dat er een vrij sterke correlatie bestaat tussen de Progressieve Matrices en de WAIS-testen $(0,40-0,75)$. Momentane invloeden spelen wellicht ook een rol (bijv. weerstand, onwil,...). Kunt u mij hier wat informatie rond bezorgen?

Bovenstaande vraag trekt de eenduidigheid en stabiliteit van intelligentiemetingen in twijfel; twee pijnpunten binnen onze testdiagnostiek die tot op heden maar beperkte aandacht gekregen hebben. Met dit artikel beogen we een kritische analyse te geven van de huidige intelligentiemetingen, gekaderd binnen de forensische praktijk. Daarnaast bespreken we de recente evolutie naar een multidimensionele benadering van het intellectueel (dis)functioneren.

\section{Intelligentie en antisociaal gedrag}

Naar schatting zou $1 \%$ van de wereldbevolking een intellectuele disfunctie ${ }^{1}$ hebben [2]. Binnen het strafrechtsysteem doen we echter een verontrustende ontdekking: het voorkomen van een intellectuele disfunctie bij daders wordt geschat op 2-10\%, afhankelijk van de instelling (bijv. gevangenis, forensische psychiatrie, enz.) en het land [3]. Ook in België ligt het voorkomen van een intellectuele disfunctie bij daders relatief hoog. Zo wordt bij $4 \%$ van de geïnterneerden die zijn opgenomen in het psychiatrisch zorgcircuit van de Federale Overheidsdienst Volksgezondheid (i.e. psychiatrische verzorgingstehuizen, de ambulante hulpverlening, instellingen tot de bescherming van de maatschappij, beschut wonen, medium security units en afdelingen binnen de algemene psychiatrie) een intellectuele disfunctie (zoals gedefinieerd in eerdere DSM-edities; i.e. IQ $<70$ ) als hoofddiagnose gesteld, in vergelijking tot $17 \%$ van de geïnterneerden die zijn opgesloten in een strafinstelling [4]. Daarnaast zou $15 \%$ van de geïnterneerden zwakbegaafd zijn, met IQ-scores tussen 70 en 85 [5]. Men gaat ervan uit dat deze cijfers een onderschatting zijn: het crimineel gedrag dat wordt vertoond door personen met een intellectu-

${ }^{1}$ In de DSM 5 werd de term 'verstandelijke beperking' of 'mentale retardatie' vervangen door 'een tekort in het intellectueel functioneren of een intellectuele disfunctie (Intellectual Disability)'. In dit artikel is er daarom voor gekozen om deze nieuwe benaming te hanteren. De WAIS-III is de derde herziene versie van de WAIS. Dit zijn de algemene categorieën zoals gebruikt in de DSM-IV TR. ele disfunctie zou onvoldoende systematisch aan de politie gerapporteerd worden [6].

Deze cijfers roepen vragen op omtrent de aard van de relatie tussen het intellectueel functioneren en antisociaal gedrag. Hoewel men deze relatie op zich niet meer in twijfel trekt, zijn er nog veel onduidelijkheden wat betreft de aard en de sterkte van de relatie. Er bestaat evidentie voor zowel een negatief verband als voor een curvilineair verband tussen IQ en antisociaal gedrag [7]. Doorgaans stelt men vast dat personen met IQscores onder de 50 maar zelden in contact komen met justitie, terwijl de groep met een lichte intellectuele disfunctie en de zwakbegaafde groep dan weer overgerepresenteerd zijn binnen de forensische populatie [8]. Een hogere IQ-score wordt als protectieve factor beschouwd [9]. Bovendien kan men niet stellen dat IQ-scores toekomstig antisociaal gedrag voorspellen. Longitudinale studies tonen aan dat een hele reeks factoren, zoals leeftijd en het neurocognitief functioneren [10], genetische factoren $[11,12]$ en gedragsproblemen [13] inspelen op de relatie tussen IQ-scores en de ontwikkeling van antisociaal gedrag. Dus in tegenstelling tot eerdere presumpties [14] kunnen we niet stellen dat lage IQ-scores op zichzelf de ontwikkeling van antisociaal gedrag voorspellen. Eerder zal de vaak complexe interactie tussen het intellectueel functioneren en andere criminogene factoren de uitkomst bepalen.

\section{De IQ-scores in twijfel getrokken}

Een betrouwbare en valide bepaling van het intelligentieniveau is binnen de forensische context van groot belang. Bij een foutieve inschatting komen twee basisprincipes van justitie zwaar in het gedrang. Justitie dient immers te verzekeren dat de betrokkene de rechten, plichten en juridische procedures ten volle begrijpt en er ook gebruik van kan maken. Daarnaast dient een aangepaste begeleiding en behandeling voor alle kwetsbare verdachten/slachtoffers/getuigen (o.a. drugsverslaafden, jongeren en personen met psychische problemen) door politie en justitie verzekerd te worden. Een foutieve inschatting van het intelligentieniveau kan bijvoorbeeld valse verklaringen tijdens het verhoor in de hand werken [15]. Verder speelt het intelligentieniveau een grote rol bij het advies aangaande de toerekeningsvatbaarheid, de inschatting van de kans op recidive en de indicatiestelling (zie bijv. [16]). In sommige landen kan een klinisch lage IQ-score een dader zelfs behoeden voor een terdoodveroordeling [17]. Een onder- of overschatting van de intellectuele capaciteiten kan met andere woorden een fair verloop van het juridische proces ernstig bedreigen. 
Intelligentiemetingen zijn echter niet feilloos of zonder meer inwisselbaar; zowel de instrumentele en temporele stabiliteit van IQ-scores worden in twijfel getrokken [18]. De diagnose van een intellectuele disfunctie is in belangrijke mate afhankelijk van welk instrument gebruikt werd om intelligentie te bepalen $[16,19]$ met alle gevolgen van dien. Ondanks het feit dat scores tussen IQ-testen op groepsniveau gecorreleerd zijn, blijken scores binnen personen vaak niet identiek te zijn [20, 21] en dit verschil is nog groter bij mensen met een intellectuele disfunctie [22, 23]. In een recente studie werd de instrumentele en temporele stabiliteit van herhaalde IQ-metingen in een forensische populatie (met en zonder intellectuele disfunctie) nagegaan [1]. Deze studie maakte deel uit van een grote Vlaamse observationele studie naar recidivecijfers bij forensische patiënten. Tijdens de dossierstudie werden van 167 patiënten (97\% mannen) dubbele IQ-scores gevonden van de Nederlandse versies van volgende intelligentietesten: de Wechsler Adult Intelligence Scale (WAIS; [24, 25]), de WAIS-III (Wechsler, [26, 27]), Raven's Progressieve Matrices (RAVEN; [28]) en de verkorte Groninger Intelligentie Test (vGIT; [29]). De langste gemiddelde tijd tussen twee afnames was, zoals verwacht, tussen de WAIS-III en de WAIS (8,6 jaar). Voor de andere vergelijkingen waren de verschillen 1,4, 3,7 en 1,3 jaar voor de vergelijking met de andere WAIS-III-score, de RAVEN en de vGIT respectievelijk. Zoals verwacht, werden hoge correlaties tussen de intelligentietesten gevonden, met de hoogste correlatie tussen de verbale subtesten van twee WAIS-IIIafnamen $(r=0,96)$ en de laagste (doch significante) correlatie tussen de totale WAIS-III-score en de score verkregen op de RAVEN $(r=0,54)$. Ook voorspelde de IQ-score van een test die van een andere test, hetgeen een goede stabiliteit tussen scores suggereert. Maar wanneer er apart werd gekeken naar de patiënten met een intellectuele disfunctie was er van stabiliteit tussen scores maar weinig sprake meer. Zo voorspelden bijvoorbeeld de WAIS-III-scores de WAIS- en de RAVEN-scores voor de gehele populatie, maar niet voor personen met een intellectuele disfunctie. Ten aanzien van het gemiddelde verschil tussen instrumenten, werden er significante verschillen gevonden tussen testen, met zelfs gemiddelde verschillen groter dan 10 punten (bijv. WAIS-III vs. RAVEN; WAIS-III vs. vGIT). Verschillen van een dergelijke orde van grootte kunnen dus betekenen dat bepaalde personen op het ene moment in de categorie 'intellectueel disfunctie' vallen en op het andere moment geclassificeerd worden als normaal begaafd, wat ook in deze studie werd vastgesteld. Aan de hand van de IQ-scores werden de personen ingedeeld in drie categorieën: normaal begaafd $(\mathrm{IQ} \geq 85)$, zwakbegaafd $(70<\mathrm{IQ}<85)$ en zwakzinnigheid (IQ $\leq 70)$. De indeling in deze categorieën was verschillend, afhankelijk van welke test gebruikt werd. In $27 \%$ van de gevallen werd aan personen een andere categorie toegewezen wanneer er twee WAIS-III-scores werden gebruikt. Dit percentage was nog hoger bij de vergelijkingen van de WAIS-III met de WAIS (48\%) en met de Raven (61\%).

Verschillen in IQ-scores kunnen meerdere oorzaken hebben. Bepaalde factoren, zoals aanpassingen in eetgewoonten [30-32], beter onderwijs of meer intellectuele stimulatie kunnen resulteren in een verandering van het IQ. Maar ook meetfouten kunnen een rol spelen en kunnen ingedeeld worden in twee brede categorieën: toevalsfouten en systematische fouten [23]. Voorbeelden van toevalsfouten zijn: fluctuaties in het gedrag van de onderzoeker, de mate van medewerking van de testpersoon en andere persoonlijke en omgevingsfactoren. Zo zal binnen de forensische context de mate van medewerking een niet te onderschatten rol spelen. Het is bijvoorbeeld mogelijk dat een persoon opzettelijk slechter presteert (malingering) om de gevangenis te vermijden of er is een gebrek aan motivatie tijdens de testafname vanwege het psychiatrisch profiel van de persoon in kwestie. Ook kan de stress die voortkomt uit een arrestatie en opsluiting ervoor zorgen dat een persoon slechter scoort. Belangrijke systematische fouten bij intelligentiemetingen zijn het vloereffect, leereffecten en het Flynn-effect. Een vloereffect houdt in dat men aan de hand van de test moeilijk een onderscheid kan maken tussen zwakke en zeer zwakke scores, omdat te veel personen een lage score op de test of subtest hebben behaald. Dit vloereffect zou meer een probleem vormen bij de Wechsler voor kinderen dan bij de Wechsler voor volwassenen [23], maar hier is nog maar heel weinig onderzoek naar gedaan. Een leereffect verwijst naar een scoreverbetering vanwege een herhaalde testafname en dient in aanmerking genomen te worden, aangezien plegers tijdens hun justitieel traject doorgaans aan meerdere intelligentiemetingen onderworpen worden. De (maar) enkele beschikbare studies suggereren dat intelligentie-instrumenten inderdaad onderhevig kunnen zijn aan leereffecten [33-35]. De vraag blijft echter over welke tijdsperiode deze leereffecten standhouden en in welke mate verschillende afnames cumulatieve effecten met zich meebrengen (zie bijv. [35]). De derde belangrijke systematische fout is het Flynn-effect, hetgeen verwijst naar de observatie van een verhoging van 0,33 punten per jaar na elke hernormering van een intelligentietest $[36,37]$. De hier beschreven fou- 
ten zouden de resultaten van Habets en collega's (2014) deels kunnen verklaren. Niettegenstaande werd echter in deze studie de tijd van afname van de IQ-testen gebalanceerd tussen proefpersonen door het feit dat de IQ-scores at random verzameld werden, waardoor de invloed van leereffecten en van het Flynn-effect werd geminimaliseerd.

De IQ-testen zijn daarenboven niet in alle doelgroepen even betrouwbaar te gebruiken. Hierbij denken we onder meer aan de psychiatrische populatie en personen met een intellectuele disfunctie. Zo kunnen IQ-scores in de loop van de tijd veranderen vanwege een psychiatrische aandoening. Bij de psychotische stoornis is er bijvoorbeeld veel discussie omtrent de progressieve achteruitgang van het cognitief functioneren $[38,39]$. Onderzoek toonde aan dat patiënten met hoge premorbide scores $(\geqslant 108)$ na hun eerste psychotische periode een daling van 10 punten lieten zien. Deze daling werd niet meer gemeten bij de follow-upmeting die gemiddeld tien jaar later werd gedaan: de IQ-scores waren namelijk weer vergelijkbaar met de premorbide scores [40]. In de groep plegers met een intellectuele disfunctie vertoont doorgaans een aanzienlijk percentage een diagnose van een psychotische stoornis $[1,41]$, wat het belang van goede diagnostiek nogmaals onderstreept. Ook de inname van psychiatrische medicatie kan een significante wijziging in het cognitief [42] en intellectueel functioneren met zich meebrengen [43]. Bij het interpreteren van IQ-scores van een forensisch patiënt moet men dus rekening houden met mogelijke schommelingen in IQ-scores vanwege een specifieke psychische stoornis en medicatie-inname. Daarnaast werden de psychometrische kwaliteiten van de IQ-testen in twijfel getrokken wanneer deze gebruikt worden bij personen met een intellectuele disfunctie [44, p. 39]. De factorstructuur van de Wechsler-schalen blijkt bijvoorbeeld immers niet stand te houden binnen deze groep $[45,46]$ en aan het lagere einde van het continuüm lijken de testen significant minder te kunnen differentiëren [45].

Om de variabiliteit in IQ-scores enigszins op te vangen, wordt het sterk aanbevolen om het betrouwbaarheidsinterval te vermelden bij de IQscore. De meeste IQ-testen rapporteren betrouwbaarheidsintervallen van ongeveer 10 punten (5 boven en 5 onder de score) [47]. Bijvoorbeeld, een WAIS-III IQ-score van 70 heeft een 95\%-betrouwbaarheidsinterval van 67-75 [27]. Maar ook deze methodiek lost het probleem niet op. Uit de studie van Habets et al. bleek immers dat een aanzienlijk aantal scores zelfs buiten het betrouwbaarheidsinterval vallen [1]. Afhankelijk van de test werd er in $33 \%$ (tot zelfs $66 \%$ ) van de gevallen een tweede score gerapporteerd die niet binnen het betrouwbaarheidsinterval viel. Mede door deze problemen onderstreept men in de recente literatuur het belang van een multidimensionele benadering van het intellectueel (dis)functioneren.

\section{Een multidimensioneel kader voor het intellectueel functioneren}

De multidimensionele benadering van intelligentie en de bijhorende diagnostiek wordt momenteel op twee domeinen onderstreept. Ten eerste wordt de focus, nu meer dan ooit, op het cognitieve vaardigheidsprofiel gelegd, met een diepgaande differentiatie van de verschillende mogelijke cognitieve vaardigheden. Ten tweede treedt bij de beoordeling van een intellectuele disfunctie het adaptief functioneren op de voorgrond en dient men dus meerdere dimensies in kaart te brengen voordat een intellectuele disfunctie vastgesteld kan worden.

Verschillende IQ-testen hebben intussen de aanvankelijk unifactoriële (focus op het IQ-cijfer) of dichotome visie (focus op de verbale en nonverbale component) op intelligentie verlaten en zijn geëvolueerd naar een multifactoriële benadering. Deze evolutie is bijvoorbeeld merkbaar in de laatste WAIS-editie. Zo komt in deze editie de dichotome structuur volledig te vervallen en benadrukt men een geoptimaliseerde vierfactorenstructuur, bestaande uit een index voor verbaal begrip, perceptueel redeneren, het werkgeheugen en de verwerkingssnelheid. Uit de recente theorieën over intelligentie blijkt echter dat ook deze vierdeling nog ontoereikend is. Een van de meest geciteerde theorieën voor cognitieve vaardigheden, met name het Cattell-Horn-Carroll (CHC) model, wordt momenteel beschouwd als het meest omvangrijke en best empirisch gevalideerd model [48]. Het model is hiërarchisch geordend in drie niveaus of zogenaamde strata. De algemene ' $g$ '-factor bevindt zich op het derde niveau en is niet rechtstreeks te meten. Deze ' $g$ 'factor is verder opgebouwd uit verschillende brede cognitieve vaardigheden (BCV), die op het tweede niveau gesitueerd worden. Dit zijn vrij basale en stabiele cognitieve eigenschappen in een persoon, die gedrag sturen en beïnvloeden. Doorgaans worden de volgende BCV's onderscheiden: vloeiende intelligentie (Gf; i.e. het vermogen om relatief nieuwe taken op te lossen), kwantitatieve kennis (Gq; i.e. verworven wiskundige kennis en wiskundig redeneren), gekristalliseerde intelligentie (Gc; i.e. verworven kennis, afhankelijk van scholing en culturele ontwikkeling), lezen en schrijven (Grw), kortetermijngeheugen (Gsm; i.e. vaardigheid om informatie kort te onthouden en 
te verwerken), visuele informatieverwerking (Gv; i.e. vaardigheden om visuele patronen en prikkels waar te nemen, te analyseren, te synthetiseren en ermee te denken), auditieve informatieverwerking (Ga; i.e. vaardigheden om auditieve prikkels te begrijpen, te analyseren en te synthetiseren), langetermijngeheugen (Glr; i.e. vaardigheid waarmee informatie efficiënt wordt opgeslagen en de toegankelijkheid van die informatie) en verwerkingssnelheid (Gs; i.e. vaardigheid om eenvoudige cognitieve taken vloeiend en automatisch uit te voeren). De BCV's bestaan op hun beurt uit meer dan 70 nauwe cognitieve vaardigheden (NCV's), ofwel de bijkomende specialisaties die vereist zijn om informatie te verwerken binnen de specifieke domeinen van de BCV's (NCV, 48). De NCV's worden via de subtesten van de intelligentie-instrumenten gemeten. Ter illustratie, de WAIS-IV-subtest 'Gewichten' gaat de NCV inductie na, hetgeen deel uitmaakt van de BCV Gf. De premisse hierbij is dat hoe meer BCV's gemeten worden, hoe nauwkeuriger men de algemene intelligentie ' $g$ ' kan inschatten (zie voor een overzicht [49]). Een gelijkaardige tendens vindt men terug in de huidige classificatiesystemen voor de definiëring van de intellectuele disfunctie. In de Diagnostic and Statistical Manual of Mental Disorders edition 5 (DSM 5) neemt men afstand van de voorheen unidimensionele benadering met een sterke focus op het IQ-cijfer. Tekorten in de intellectuele vaardigheden worden nu aan de hand van tekorten op verscheidene cognitieve domeinen 'als het redeneervermogen, de probleemoplossende vaardigheden, planning, abstract denken, oordeelsvermogen, academisch leren, en het leren uit ervaring' beschreven [50].

De bepaling van de intellectuele vaardigheden (en beperkingen) dient met andere woorden gebaseerd te zijn op een breed assessment in combinatie met het klinisch oordeel van de clinicus [50], en dus niet meer louter op basis van een intelligentietest. Greenspan en Woods opperen daarom dat een breed assessment enkel mogelijk gemaakt kan worden door gebruik te maken van neuropsychologische testen [51]. Maar net als in de DSM ontbreekt het hier aan een theoretisch kader, waardoor de kans reëel blijft dat men belangrijke vaardigheden in de diagnostiek zal missen. Een theoriegedreven diagnostiek is hier eerder aan te raden. In Vlaanderen is er echter momenteel geen enkele test die een theoriegedreven (bijv. CHC-gedreven) assessment van de cognitieve vaardigheden toelaat. Dit geldt ook voor de Wechsler-schalen die een duidelijk theoretisch kader missen. Indien men de Wechsler-schalen bijvoorbeeld binnen het CHC-kader evalueert, blijken de laatste edities belangrijke vaardigheden als auditieve informatieverwerking $(\mathrm{Ga})$ en langetermijn- geheugen (Glr) niet te meten [52]. Bovendien geeft een dergelijke theoretische evaluatie de toch wel frappante inhoudelijke verschillen tussen de courant gehanteerde intelligentie-instrumenten. Zo blijkt de totaalscore van de Raven een inschatting te geven van slechts één bepaalde component van het intellectueel functioneren, met name de Gf, in tegenstelling tot bijvoorbeeld de WAIS-III, die Gf, Gc, Gv, Gsm en Gs in kaart brengt (zie ook [53]). Dergelijke inhoudelijke verschillen kunnen dus tevens (deels) ten grondslag liggen aan verschillen tussen intelligentiescores die zijn verkregen op basis van verscheidene instrumentaria.

Een CHC-gedreven diagnostiek zou evenwel verscheidene voordelen met zich meebrengen. Ze biedt niet alleen een eenduidige nomenclatuur aan, ze geeft ook een kader voor onder meer een diepgaande differentiaaldiagnostiek tussen onder andere leerproblemen, taalstoornissen en intellectuele disfuncties. Daarnaast biedt deze vorm van diagnostiek concrete handvatten om begeleidingen en behandelingen aan te passen aan de individueles sterktes en zwaktes vanuit het CHC-profiel van de patiënt (bijv. [54, 55-57]). Wil men zoveel mogelijk BCV's in kaart brengen, dan is men momenteel aangewezen op een crossbatterijbenadering, waarbij aan een bepaalde intelligentietest subtesten uit andere kwaliteitsvolle testen worden toegevoegd (zie bijv. [52]). De Woodcock-Johnson III Tests of Cognitive and Achievement Abilities (WJ III, [58]), bij de ontwikkeling waarvan het $\mathrm{CHC}$-model gehanteerd werd, biedt in de Angelsaksische landen momenteel het enige alternatief voor de crossbatterijbenadering. De eerste Vlaamse intelligentietest volgens het CHC-model is de Cognitieve Vaardigheidstest volgens het CHC-model (CoVaT-CHC, [59]), waarvan de eerste versie binnenkort verschijnt. Deze basisversie zal nog niet alle BCV's dekken; de verwachting is dat dit in de volgende versies in grotere mate het geval zal zijn.

Voor het inschatten van een intellectuele disfunctie is het niet alleen van belang om een multidimensionele benadering van intelligentie toe te passen, maar ook om de klemtoon te leggen op het adaptief (dis)functioneren [6o], zoals ook in de laatste editie van de DSM wordt beklemtoond [50]. Onder adaptief functioneren verstaat men doorgaans drie categorieën van vaardigheden: (1) de conceptuele vaardigheden, waaronder taalvaardigheid, geletterdheid, en een begrip van geld, tijd en numerieke concepten; (2) de sociale vaardigheden, waaronder empathie, communicatievaardigheden en zelfregulatie, en (3) de praktische vaardigheden, waaronder geldbeheer, zelfzorg en organisatie van werk en school. De inschatting van het adaptief functioneren dient 
dus een prominentere rol te krijgen binnen de diagnostiek van het intellectueel functioneren, aangezien adaptief functioneren de beste indicator zou zijn voor de bepaling van de aard en de intensiteit van de begeleiding. Meer nog, volgens de criteria van de DSM 5 dient de ernst van de intellectuele disfunctie bepaald te worden aan de hand van het functioneren op de drie voorgenoemde domeinen. Hierbij dient er wel een duidelijke link te zijn tussen het intellectueel en adaptief disfunctioneren. Hoe men dit naar de testdiagnostiek kan vertalen, blijft nog de vraag [51]. In Vlaanderen stuit men op een bijkomend prangend probleem: voornamelijk voor de volwassen doelgroep ontbreekt het tot op heden aan kwaliteitsvolle instrumenten voor de meting van het adaptief functioneren die inhoudelijk alle relevante subdomeinen van het adaptief functioneren meten, die aan de psychometrische vereisten van validiteit en betrouwbaarheid voldoen, en die voor de Nederlandstalige algemene, laat staan de forensische, populatie genormeerd zijn [61]. Daarenboven verblijven forensische cliënten vaak in een gesloten, beveiligde omgeving, wat de evaluatie van het adaptief functioneren sterk bemoeilijkt. Het is immers binnen deze omgeving niet mogelijk om alle relevante gedragingen te observeren en/of derden (bijv. de ouders) als informant te gebruiken, wat wel een vereiste is voor een betrouwbare en valide inschatting van het sociaal aanpassingsvermogen.

\section{Conclusie}

Het belang van een kwaliteitsvolle meting van het intellectueel (dis)functioneren kan niet voldoende onderstreept worden. Dit is zo binnen de forensische werkcontext, maar geldt zonder twijfel ook in andere contexten. De beperkingen van intelligentietesten in rekenschap nemend, is een kritische houding ten aanzien van intelligentietesten en -scores dan ook onontbeerlijk. Dit is echter geen pleidooi om het kind met het badwater weg te gooien; de huidige intelligentietesten blijven een belangrijke tool om op objectieve wijze het intellectueel functioneren in kaart te brengen. Deze kritische houding dient zich bij voorkeur te vertalen in onder meer genuanceerde conclusies die men op basis van de intelligentiemeting trekt, en een voortdurend streven naar de verdere optimalisering van deze diagnostiek, door onder meer het intellectueel functioneren op multidimensionele wijze te benaderen.

\section{Literatuur}

1. Habets P, Jeandarme I, Uzieblo K, Oei K, Bogaerts $S$. Intelligence is in the eye of the beholder: investigating repeated IQ measurements in forensic psychiatry. J Appl Res Intellect Disabil. 2015:28(3):182-92. Epub ahead of print 2014 Sept 1. (PubMed PMID: 25175692).

2. Maulik PK, Mascarenhas MN, Mathers CD, Dua T, Saxena S. Prevalence of intellectual disability: a meta-analysis of population-based studies. Res Dev Disabil. 2011;32(2):419-36. (PubMed PMID: 21236634).

3. Lindsay WR. People with intellectual disability who offend or are involved with the criminal justice system. Curr Opin Psychiatry. 2011;24(5):377-81. (PubMed PMID: 21587076).

4. Cosyns P. Werkgroep Forensisch Psychiatrisch Zorgcircuit: syntheseverslag mei 2005. Brussel: Federale Overheidsdienst Justitie; 2005.

5. Maes B, Goethals J, Verlinden S. Personen met een verstandelijke beperking onderhevig aan een interneringsmaatregel. Leuven: Steunpunt Welzijn, Volksgezondheid en Gezin; 2009.

6. Jones J. Persons with intellectual disabilities in the criminal justice system: review of issues. Int J Offender Ther Comp Criminol. 2007;51(6):72333. (PubMed PMID: 17636203).
7. Mears DP, Cochran JC. What is the effect of IQ on offending. Crim Justice Behav. 2013;40(11):1280-300.

8. Lindsay WR, Hastings RP, Beail N. Why do some people with intellectual disability engage in offending behaviour and what can we do about it? Editorial. J Appl Res Intellect Disabil. 2013;26(5):351-6. (PubMed PMID: 23925957).

9. Portnoy J, Chen FR, Raine A. Biological protective factors for antisocial and criminal behavior. J Crim Justice. 2013;41(5):292-9.

10. Loeber R, Menting B, Lynam DR, Moffitt TE, Stouthamer-Loeber M, Stallings R, et al. Findings from the Pittsburgh Youth Study: cognitive impulsivity and intelligence as predictors of the age-crime curve. J Am Acad Child Adolesc Psychiatry. 2012;51(11):1136-49. (PubMed PMID: 23101740).

11. DeYoung CG, Peterson JB, Seguin JR, Mejia JM, Pihl RO, Beitchman JH, et al. The dopamine D4 receptor gene and moderation of the association between externalizing behavior and IQ. Arch Gen Psychiatry. 2006;63(12):1410-6. (PubMed PMID: 17146015. Pubmed Central PMCID: 3283582). 
12. Koenen KC, Caspi A, Moffitt TE, Rijsdijk F, Taylor A. Genetic influences on the overlap between low IQ and antisocial behavior in young children. J Abnorm Psychol. 2006;115(4):787-97. (PubMed PMID: 17100536 . Pubmed Central PMCID: 2254220).

13. Lahey BB, D’Onofrio BM, Hulle CA Van, Rathouz PJ. Prospective association of childhood receptive vocabulary and conduct problems with self-reported adolescent delinquency: tests of mediation and moderation in siblingcomparison analyses. J Abnorm Child Psychol. 2014;42(8):1341-51. (PubMed PMID: 24736982. Pubmed Central PMCID: 4198452).

14. Herrnstein RJ, Murray C. The Bell curve: intelligence and class structure in American life. New York: The Free Press; 1994.

15. Kassin SM. The psychology of confessions. Ann Rev Law Soc Sci. 2008;4(1):193-217.

16. Toorn B Van, Bon C. De onbetrouwbaarheid van de IQ-meting. De Psycholoog. 2011;45:4-9.

17. Appelbaum PS. Hall v. Florida: defining intellectual disability in the shadow of the death penalty. Psychiatr Serv. 2014;65(10):1186-8. (PubMed PMID: 25270493).

18. Evans IM. Testing and diagnosis: a review and evaluation. In: Meyer LH, Peck CA, Brown L, editors. Critical issues in the lives of people with severe disabilities. Baltimore (MD): Brookes Publishing Co; 1991.

19. Casey P, Keilitz I. Estimating the prevalence of learning disabled and mentally retarded juvenile offenders: a meta-analysis. In: Leone PE, editor. Understanding troubled and troubling youth. Newbury Park: Sage; 1990. pp. 82-101.

20. Di Nuovo AG, Di Nuovo S, Buono S. Intelligent quotient estimation of mental retarded people from different psychometric instruments using artificial neural networks. Artif Intell Med. 2012;54(2):135-45. (PubMed PMID: 22153923).

21. Floyd RG, Clark MH, Shadish WR. The exchangeability of IQs: implications for professional psychology. Prof Psychol Res Pract. 2008;39:414-23.

22. Silverman W, Miezejeski C, Ryan R, Zigman W, Krinsky-McHale S, Urv T. Stanford-Binet \& WAIS IQ differences and their implications for adults with intellectual disability (aka mental retardation). Intelligence. 2010;38(2):242-8. (PubMed PMID: 20401180. Pubmed Central PMCID: 2854585).

23. Whitaker S. Error in the estimation of intellectual ability in the low range using the WISCIV and WAIS-III. Personal Individ Differ. 2010;48(5):517-21.

24. Wechsler D. Manual for the Wechsler adult intelligence scale WAIS. New York: Psychological Corporation; 1955.

25. Wechsler D. WAIS Dutch adaptation. Technical manual [WAIS Nederlandstalige bewerking. Technische Handleiding]. Amsterdam: Swets \& Zeitlinger; 1970.
26. Wechsler D. The Wechsler adult intelligence scale - Third Edition. San Antonio: The Psychological Corporation; 1997.

27. Wechsler D. WAIS-III Dutch adaptation. Technical manual [WAIS-III Nederlandstalige bewerking. Technische Handleiding]. Lisse: Swets \& Zeitlinger; 2005.

28. Raven J, Raven JC, Court JH. Manual for Raven's progressive matrices and vocabulary scales. San Antonio: Harcourt Assessment; 1998.

29. Kooreman A, Luteijn F. The short format of the Groningen Intelligence Test [Groninger Intelligentie Test: schriftelijke verkorte vorm]. Lisse: Swets \& Zeitlinger; 1987.

30. Bellisle F. Effects of diet on behaviour and cognition in children. Br J Nutr. 2004;92(Suppl 2):S227-32. (PubMed PMID: 15522161).

31. Koyama KI, Asakawa A, Nakahara T, Amitani H, Amitani M, Saito M, et al. Intelligence quotient and cognitive functions in severe restrictingtype anorexia nervosa before and after weight gain. Nutrition. 2012;28(11-12):1132-6. (PubMed PMID: 23044164).

32. Smithers LG, Golley RK, Mittinty MN, Brazionis L, Northstone K, Emmett P, et al. Dietary patterns at 6,15 and 24 months of age are associated with IQ at 8 years of age. European journal of epidemiology. 2012;27(7):525-35. (PubMed PMID: 22810299).

33. Wechsler D, editor. WAIS-IV Dutch adaptation. Technical Manual [WAIS-IV Nederlandstalige bewerking. Technische Handleiding]. Lisse: Swets \& Zeitlinger; 2012.

34. Estevis E, Basso MR, Combs D. Effects of practice on the Wechsler Adult Intelligence Scale-IV across $3^{-}$and 6-month intervals. Clin Neuropsychol. 2012;26(2):239-54. (PubMed PMID: 22353021).

35. Staff RT, Hogan MJ, Whalley LJ. Aging trajectories of fluid intelligence in late life: the influence of age, practice and childhood IQ on Raven's Progressive Matrices. Intelligence. 2014;47:194-201.

36. Flynn JR. The mean IQ of Americans: massive gains 1932 to 1978. Psychol Bull. 1984;101:171-91.

37. Trahan LH, Stuebing KK, Fletcher JM, Hiscock M. The Flynn effect: a meta-analysis. Psychol Bull. 2014;140(5):1332-6o. (PubMed PMID: 24979188. Pubmed Central PMCID: 4152423).

38. Heaton RK, Gladsjo JA, Palmer BW, Kuck J, Marcotte TD, Jeste DV. Stability and course of neuropsychological deficits in schizophrenia. Arch Gen Psychiatry. 2001;58(1):24-32. (PubMed PMID: 11146755).

39. Zampera E. Intellectual performance of chronic schizophrenic patients. Coll Antropol. 1999;23(2):597-602. (PubMed PMID: 10646233).

40. Winkel R van, Myin-Germeys I, Delespaul P, Peuskens J, Hert M De, Os J van. Premorbid IQ as a predictor for the course of IQ in first onset patients with schizophrenia: a 10-year follow-up study. Schizophr Res. 2006;88(1-3):47-54. (PubMed PMID: 16904292). 
41. Dias S, Ware RS, Kinner SA, Lennox NG. Cooccurring mental disorder and intellectual disability in a large sample of Australian prisoners. Aus N Z J Psychiatry. 2013;47(10):938-44. (PubMed PMID: 23723292).

42. Levin R, Dor-Abarbanel AE, Edelman S, Durrant AR, Hashimoto K, Javitt DC, et al. Behavioral and cognitive effects of the N-methyl-D-aspartate receptor co-agonist D-serine in healthy humans: initial findings. J Psychiatric Res. 2015;61:188-95. (PubMed PMID: 25554623).

43. Gimpel GA, Collett BR, Veeder MA, Gifford JA, Sneddon P, Bushman B, et al. Effects of stimulant medication on cognitive performance of children with ADHD. Clin Pediatr 2005;44(5):405-11. (PubMed PMID: 15965546).

44. Schalock RL, Verdugo MA, Gomez LE. Evidence-based practices in the field of intellectual and developmental disabilities: an international consensus approach. Eval Program Plann. 2011;34(3):273-82. (PubMed PMID: 21167602).

45. MacLean H, McKenzie K, Kidd G, Murray AL, Schwannauer M. Measurement invariance in the assessment of people with an intellectual disability. Res Dev Disabil. 2011;32(3):1081-5. (PubMed PMID: 21296555).

46. Reynolds MR, Ingram PB, Seeley JS, Newby KD. Investigating the structure and invariance of the Wechsler Adult Intelligence Scales, Fourth Edition in a sample of adults with intellectual disabilities. Res Dev Disabil. 2013;34(10):3235-45. (PubMed PMID: 23891724).

47. Whitaker S. Intellectual disability: a concept in need of revision. Br J Dev Disabil. 2008;54:3-9.

48. McGrew KS. Editorial: CHC theory and the human cognitive abilities project: standing on the shoulders of the giants of psychometric intelligence research. Intelligence. 2009;37:1-10.

49. Keith TZ, Reynolds MR. Cattell-horn-carroll abilities and cognitive tests: what we've learned from 20 years of research. Psychol Sch. 2010;47(7):635-50.

50. American Psychiatric Association. Diagnostic and statistical manual of mental disorders. 5th ed. Washington, DC: APA; 2013.

51. Greenspan $S$, Woods GW. Intellectual disability as a disorder of reasoning and judgement: the gradual move away from intelligence quotientceilings. Curr Opin Psychiatry. 2014;27(2):110-6. (PubMed PMID: 24441419).
52. Flanagan DP, Ortiz SO, Alfonso VC. Essentials of cross-battery assessment 3th ed. New Jersey: John Wiley \& Sons, Inc.; 2013.

53. Alfonso VC, Flanagan DP, Radwan W. The impact of Cattell-Horn-Carroll theory on test development and interpretation of cognitive and academic abilities. In: Flanagan DP, Harrison PL, editors. Contemporary intellectual assessment: theories, tests, and issues. New York: Guilford Press; 2005. pp. 185-202.

54. Fiorello CA, Primerano D. Research into practice: Cattell-Horn-Carroll cognitive assessment in practice: eligibility and program development issues. Psychol Sch. 2005;42:525-36.

55. Niileksela CR, Reynolds MR. Global, broad, or specific cognitive differences? Using a MIMIC model to examine differences in CHC abilities in children with learning disabilities. J Learn Disabil. 2014;47(3):224-36. (PubMed PMID: 22907885).

56. Proctor B. Relationships between Cattell-HornCarroll (CHC) cognitive abilities and math achievement within a sample of college students with learning disabilities. J Learn Disabil. 2012;45(3):278-87.(PubMed PMID: 21571701).

57. Uzieblo K, Winter J, Vanderfaeillie J, Rossi G, Magez W. Intelligent diagnosing of intellectual disabilities in offenders: food for thought. Beh Sci Law. 2012;30(1):28-48. (PubMed PMID: 22241548).

58. Woodcock RW, McGrew KS, Mather N. Woodcock-Johnson III tests of cognitive abilities. Itasca: Riverside Publishing; 2001.

59. Magez W, Tierens M, Huynegem J Van, Parijs K Van, Decaluwé V, Bos A. CoVaT-CHC Basisversie. Cognitieve Vaardigheidstest volgens het $\mathrm{CHC}$ model. Antwerpen: Thomas More; 2015.

6o. American Association on Intellectual and Developmental Disabilities. Definition of Intellectual Disability 2015. Beschikbaar via http://aaidd. org/intellectual-disability/definition/faqs-onintellectual-disability\#.VRv8EbpsCSA. Geraadpleegd 15 juni 2015.

61. Vlaams Agentschap voor Personen met een Handicap (VAPH). Classificerende diagnostische protocollen. 2011-2012. Beschikbaar via www. vaph.be/vlafo/download/nl/8229547/bestand. Geraadpleegd 15 juni 2015. 